\title{
A New Alliance against the US? Sino- Russian Relations in Response to Trump's Redefined Foreign Policy Priorities
}

\author{
Przemysław Ciborek \\ University of Łódź \\ Faculty of International and Political Studies \\ Department of East Asian Studies \\ e-mail: przemyslaw.ciborek@uni.lodz.pl
}

\section{Abstract}

The current state of bilateral relations between the Russian Federation and the People's Republic of China is described by many international relations experts as the best in history. After taking the president office by Donald Trump, the bilateral relations between America and abovementioned powers are cooling down. Current foreign policy of the People's Republic of China and the Russian Federation focuses on holding a common position in the international political arena, which is in fact an attempt to counterweight political influence of the US administration and their allies. The dimension of the strategic partnership between China and Russia is also determining the mutual economic dependence, which is now crucial for both powers to build a strong position on the international forum. In addition, Russia is one of the crucial partners for the Chinese-led Belt and Road Initiative (BRI) - by many recognized as the Chinese attempt to break the American economic domination. The collisional course of the American foreign policy towards Russia and China forces the latter to look for Central and Eastern European allies as well as to gain influence in the region of Central Asia which is leading to a constant increase in tensions between China and Russia.

Keywords: China, Russia, USA, Donald Trump, Barack Obama, Vladimir Putin, Xi Jinping, bilateral relations, Pivot to Asia, economic protectionism, economic sanctions 


\section{Obama's "Pivot to Asia" versus Trump's conservative policy}

After Barack Obama took an office in 2009, it became clear that the withdrawal of the US Army from the Middle East would take place over the course of the next months. As a counterbalance to these activities, the president's administration focused on increasing its political and economic presence in the Asia-Pacific region. The motivation for this action has been the aggregation of four key factors (Manyin, 2): 1) the elimination of US military presence in Iraq and Afghanistan; 2) growing economic importance of the Asia-Pacific area (PRC, ASEAN); 3 ) the growing military capabilities of the People's Liberation Army and the growing tension on the South China Sea; 4) cuts in federal spending on military, which has raised concerns about US meeting commitments to the region'.

"Pivot to Asia" during the Barack's Obama presidency assumed six key objectives $^{2}$, whose fulfillment was to result in strengthening the US bilateral alliances in the region, primarily with long-term allies like Japan and the Philippines. The main problem with regard to the implementation of those objectives - considered not only in terms of rhetoric but also real actions - was the beginning of President Obama's so-called "Asian Tour" starting from his visit to Japan and the ending in the Philippines, was the agreement allowing the US military presence in the region to be increased. Shortly thereafter, many experts categorized the agreement as an attempt to counterbalance the growing military potential of the PRC in the region. A few days later, these allegations were expressly rejected by the American president. "Pivot to Asia" during the Obama's presidency - despite economic and diplomatic efforts - did not reach intended effects. The manifestation of the US military power in the countries of the Southeast Asia consistently

1 On the basis of the Security Treaty between the United States and Japan, signed on August 8, 1951 in San Francisco. According to Art. 1 - the government of Japan will make its territory available to create an overseas base for the American army. Japan with accordance to the Article 9 of the national constitution renounces use of the military aggression as a mean of resolving international disputes and in order to implement this plan, does not maintain armed forces on its territory. In this context, the treaty of August 8, 1951 should be interpreted as an American protectorate over military security and the sovereignty of Japan.

2 Strengthening bilateral relations with US long-term allies in the region: Japan, South Korea, Australia, Philippines and Thailand; 2) improvement of bilateral relations with the emerging Asian economic powers: China, India, Indonesia, Singapore, New Zealand, Malaysia, Mongolia, Vietnam and Brunei; 3) political involvement in multilateral organizations operating in Southeast Asia: Association of Southeast Asian Nations (ASEAN) and Asia-Pacific Economic Cooperation Forum (APEC); 4) increase in economic exchange and investments in the region through the development of Trans-Pacific Partnership (TPP); 5) increasing the presence and military activity in the region of Southeast Asia; 6) promoting democracy and defending human rights in the region of Southeast Asia. 
antagonized China, which treated the growth of the US military presence as an attempt to violate their vital military and economic interests, which ultimately led to a slow erosion of bilateral relations between Beijing and Washington (Anderson, Parker, 11-12).

When comparing the presidency of Barack Obama with that of Donald Trump regarding relations with the Far East, it should be noted that their quality was a subject of further erosion. The president elect immediately after the publication of the presidential election results in December 2016 committed a diplomatic scandal, accepting a telephone conversation with the Republic Of China President, Tsai Ing-wen. Breaking the decades-long rule on Taiwan's non-recognition policy was only the tip of the iceberg, because shortly after this event, Trump questioned the legitimacy of the "One China" policy, accusing the Chinese government of manipulating the Chinese currency afterwards. In addition, during the election campaign, Donald Trump criticized the presence of US troops stationing in Japan and South Korea, claiming that this is unprofitable and if interested parties do not start to participate more actively in the cost of maintaining the US Army missions, the American government should consider a withdrawal of its troops (Wright). During Xi-Trump phone conversation held on February 9, 2017, there was an unexpected turn of events, because the American president assured his Chinese counterpart about respecting the "One China" policy, eventually leading to the meeting of two leaders on April 7, 2017. The April meeting at Mar-a-Lago led to the promotion of the development of mutual trade and investment and the implementation of the "100-Day Action Plan," which assumed increased exports of American goods to China in order to overcome the deficit in bilateral trade with the PRC (Bartsch, 116-117).

There was a strong need of normalization of Russian-American bilateral relations during Obama's presidency. As it turned out, after the meetings of the heads of diplomacy - Hilary Clinton and Sergei Lavrov in March 2009, the Russian Federation has definitely benefited from the reset in bilateral relations. The withdrawal of American troops from the Central Asia region, agreement on the reduction of strategic nuclear arsenals (START, February 2011) and cooperation of the American ExxonMobil and Rosneft on the use of the Arctic shelf in Russia for the price of political agreement with regard to the third round of sanctions in the UN Security Council which were aimed at the Russian ally - Iran ${ }^{3}$, after couple of years proved to be beneficial for a country then ruled by Dmitry Medvedev. A significant deterioration of US-Russia relations took place after the presidential election in 2012 in Russia, when Vladimir Putin came to power in 2012. The Russian president shortly after the election refused to participate in the G8 summit at Camp

3 An agreement between USA and Russia (2010) on air operations in Teheran, Iran. Sanctions did not affect bilateral relations between Iran and Russia. Ultimately, sanctions began to be successively abrogated by Resolution 2231 of the UNSC of 22 July 2015. 
David, which in the rematch led to Obama's absence at the APEC summit in Vladivostok (Menkiszak, 39). The next crisis in bilateral relations was related to the person of Edward Snowden who in June 2013 unmasked the activities of American intelligence related to Russia. Diplomatic relations deteriorated even further after the Russian annexation of the Crimean peninsula in March 2014, which resulted in the imposition of economic sanctions from the US and the EU on Russia.

The opportunity to improve bilateral relations was expected after the election of Donald Trump as the $45^{\text {th }}$ President of the United States of America, but on April 7, 2017 Trump decided to strike at the Syrian airbase Shayrat after the attack on civilians in Khan Shaykhun. Secretary of State Rex Tillerson said at the time that "Russia has not fulfilled its commitment since 2013, so either it was complicit in the attacks or is incompetent in its ability to comply with the contract."4 There were voices among Russian society and media that Trump has committed an act of betrayal on Russia (Rutland, 53). On August 2, 2017, Trump signed the law on tightening sanctions against Russia due to the Russian interference in the 2016 US elections. Imposed sanctions resulted in Moscow's reaction to reduce the number of employees of US diplomatic missions in Russia (Rampton, Zengerle).

\section{Sino-Russian relations before the Donald Trump presidency}

There was a noticeable turn towards the East in Russia's foreign policy over the last decade since the APEC summit in Vladivostok, which took place in September 2012. At the time, the main motivation of the Russian Federation government was the development of the eastern territories of the country based on economic cooperation with China, Japan and South Korea. It was the part of the existing federal program "Far East Development Strategy," which is to be evaluated by 2025. Cooperation with Asian countries was also intended to balance economic dependence on contacts with the European Union countries. Sino-Russian relations were also improved after the introduction of Belt and Road initiative by PRC Chairman Xi Jinping back in 2013. Russia has become the most important partner on the land section of this initiative due to its geographical location. The key factor for China in this matter was political stability of Russia as well as the friendly relations of Xi Jinping with Vladimir Putin.

A turning point in Sino-Russian relations was the Ukrainian crisis, where the return to the Far East development strategy was to compensate for the losses incurred as a result of the imposition of economic sanctions on Russia by the Western coalition. The economic impacts on Russian society probably exceeded the estimates

4 The commitment concerned the destruction of the Syrian chemical arsenal. 
of native experts, so the Russian government decided to stress further cooperation towards Asian countries. During the Russia-ASEAN summit in Sochi in 2016, Russian government proposed the establishment of a free trade zone between the Eurasian Economic Union and the ASEAN. Russian plan did not meet with the enthusiasm of the countries concerned and although it was not definitively rejected, the political price borne by the Russian government included the support of ASEAN states regarding the situation in the South China Sea, which significantly harmed the interest and policy of the PRC in the region. To ease the tension between Moscow and Beijing with regard to Russian Support of ASEAN countries with regard to South China Sea, joint military exercises were held in the East China Sea near Diaoyu/Senkaku islands disputed between China and Japan. At that time, it raised the concerns of ASEAN member states regarding the further development of the Sino-Russian naval program.

\section{A Chinese-Russian alliance during the Donald Trump presidency}

Strengthening economic cooperation between China and Russia was a response to the signals sent by Donald Trump in early 2017, which has resulted in further deterioration of trade exchange of China and Russia with the US. America First policy pushed by the US president involved imports reduction and rebuilding of the country's industrial base by providing tax incentives for domestic entrepreneurs with strong anti-China rhetoric presented during the presidential campaign, which is characteristic for the economic protectionism (Polityka Insight, Co przyniesie prezydentura Trumpa?).

On January, 2017 the World Economic Forum in Davos was held. During the absence of the US administration as well as the German Chancellor Angela Merkel and French President Francois Hollande, the president of the PRC, Xi Jinping was the one who stood up for capitalism. During his speech, he emphasized that "striving for protectionism is like closing yourself in a dark room. Although wind and rain will not get inside, so will light and air. Therefore, no one will come out victorious from trade wars" (Kowalski). This kind of a message was meant to be an allusion to planned US development strategy.

Xi Jinping's visit to Moscow on July 3-4, 2017 was also a clear signal before the G2O summit held later that month in Hamburg, Germany. As expected, the Sino-Russian political and economic alliance influenced the position taken by both sides. China and Russia became the target of the American administration, which in the words of Rex Tillerson clearly expressed its disapproval on North Korea issue, blaming China and Russia for stagnation and the lack of decisive action to resolve the conflict. 
The People's Republic of China and its government have been trying to limit US military and political presence in the region for decades. During the very first day in office, Donald Trump facilitated this task of the current PRC administration by implementing the announced US withdrawal from the Trans-Pacific Partnership (TPP). TPP was a pillar of Barack Obama's policy, but according to the new president, the agreement was classified in terms of a catastrophe that devastated the American economy. On January 23, 2017, Prime Minister of Australia announced that China could consider taking the place of US in TPP (Ashraf). China was not interested in such proposition and consistently promoted its own initiative - Regional Comprehensive Economic Partnership (RCEP). In addition, Japanese Prime Minister Abe Shinzo stated that TPP without the US was losing its importance and it did not make any sense to continue it.

When analyzing the economic dimension of Sino-Russian cooperation, it should be noted that Russia is only the 1oth trading partner of the People's Republic of China (2016). The value of exchange between countries for 2016 valued USD 66 billion (ICT Trade Map). What is worth mentioning, this value is almost ten times lower than the value of the China-US trade exchange in the same period. The Russians owe their position almost exclusively to the export of fossil fuels to China. The relatively low value of bilateral exchange prompted the leaders of both countries to intensify economic cooperation. On July 4, 2017, $\mathrm{Xi}$ and Putin announced the creation of an investment fund in the amount of USD 10 billion and establishment of an innovation fund in the amount of USD 850 billion to improve trade routes at the Sino-Russian border crossing points. On August 2, 2017, the head of the Ministry of Development of the Russian Federation, Maksim Oreshkin stated that in 2017 trade turnover had risen by $37 \%$ by that date, while further growth in economic exchange was being hampered by infrastructural obstacles. Projection of trade value for that time until the end of 2017 was about to reach unprecedented USD 80 billion. Russian government-backed Rosneft showed its determination in this matter, doubling the export of oil barrels to the level of 600,000 per day by the end of 2018, thus ignoring the export limits imposed by the OPEC. In November 2017, Vladimir Putin announced to the public that the real value of the Sino-Russian exchange should reach USD 66 billion, and therefore it should remain at the level from 2016. Taking into the account the increased export activity of the Russian Federation regarding the supply of fossil fuels, it should result in a rapid increase in terms of the value of trade. Relatively low value of the Russian export resulted from the decline in oil and gas prices on the global market, caused indirectly by the imposition of economic sanctions on Russia (Ośrodek Spraw Azjatyckich UŁ). The Sino-Russian trade exchange was also the subject of stimulation under international agreements and organizations, including BRICS. The financial institution of this organization, i.e. New Development Bank approved a loan 
of USD 1.4 billion, where in Russia these funds would be used in full to invest in infrastructure (Financial Express).

In the field of military cooperation, joint military operations of China and Russia are permanently inscribed in the calendar of both ministries since the rise of the tensions between Moscow and Washington in 2012. Intensification of joint military projects took place after the publication of the Belt and Road initiative and both countries supported their efforts in international fora, for example on conflicts in Syria and North Korea. An example of such activities are joint exercises in the Sea of Okhotsk within 100 miles from the border with North Korea. Joint exercises of China and Russia navy in the face of the Korean crisis had a specific effect. Above all, it was a clear message addressed to the international opinion with exemplary economic and political cooperation, which further confirms the common position on the current international challenges in the UN Security Council. Secondly, it was the call of the United States to limit its military influence in the region of Southeast Asia, primarily in the context of joint military exercises between the US and South Korea armies. It was also a demonstration of the strength and the momentum of the Chinese Navy. In the context of the July's 2017 Sino-Russian exercises in the Baltic Sea (Higgins), the long-term geopolitical plans of the PRC are referred to the region of Europe and it is clear that these plans would be implemented with Russian participation. In return, Russian decision-makers expected support from Chinese activities in Ukraine, while in the face of a vital Chinese interest in Ukraine as part of the Belt and Road initiative, Chinese administration was using a skillful diplomatic language, which does not condemn or strongly support any of the parties to the conflict, calling only for solving the issues with accordance to international law (Permanent Mission of the People's Republic of China to the UN).

Defining the main goals of China's foreign policy in the context of Russia, the energy needs of the Middle Kingdom are at the forefront. On a global scale, over the last decade, energy demand has increased by $20 \%$, while in China alone there was an increase of $220 \%$. The Chinese have mercilessly used the imposition of economic sanctions on Russia, resulting in a fall in prices of fossil fuels, concluding further contracts under attractive conditions. Since March 2017, Russia is the largest supplier of crude oil to China. The volume of exports is 1.3 million barrels per day. In September 2017, a 14\% minority stake in Rosneft was taken over by CEFC China Energy (Huaxin) for USD 9.1bn (Reuters, Rosneft board approves oil deal with China's CEFC), and there is a plan of launching the Power of Siberia pipeline, which completion is scheduled to 2019, where the Russian giant Gazprom is required to sign 30-year gas supply contract for the state-owned China National Petroleum Corporation (Graeber).

Another strategic goal of the Chinese administration is to include the Eurasian Economic Union in the Belt and Road initiative, by creating a free trade zone with 
China. Implementation of the Chinese plan would definitely improve the process of certification and customs clearance of goods exported towards Western Europe, on the other hand, depriving EAEU of the main source of the financing, ultimately marginalizing its international importance, which is contrary to the interests of the Russian government.

Chinese officials are also striving to change the character of the functioning of the Shanghai Cooperation Organization, which until now was a function of cooperation on the security of the countries in the region. The creation of duty-free transit corridors is also planned here, which would make the Chinese initiative more attractive internationally. However, during the SCO summit in June 2017, the conflict of interests between Russia and China once again became apparent. Despite joining the long-term ally of China - Pakistan, Beijing may lose influence within the organization itself and among the EAEU countries. The reason for this is the simultaneous accession of India to the organization, which, according to Russia, may limit Chinese influence in Central Asia. Moreover, given the unresolved territorial disputes between India and Pakistan, there is a possible escalation of the conflict, which may lead to the split of two blocs within the organization itself, whose political leaders would probably be Russia and China.

The Chinese attempt to dethrone the US as a global economic power - with the political support of Moscow - also has a pragmatic dimension, an example of which is the attempt to internationalize the Chinese currency. Establishment of Chinese financial institutions, including the Asian Infrastructure Investment Bank is to compete with the Western-dominated capital of the International Monetary Fund, the World Bank or the Asian Development Bank, or in the worst case it is to be an alternative to them. On November 1, 2017, Chinese Prime Minister Li Keqiang met with his Russian counterpart Dmitry Medvedev with regard to the merger of the payment systems dominating in the country, Chinese UnionPay and the Russian Mir Card, to limit the dominance of the American Visa and MasterCard systems (Daly).

\section{Conclusions}

The Russian Federation, as a country with lower economic and demographic potential, is exposed to the necessity of accepting Chinese hegemony in the region. Economic sanctions forced Russia to direct its supply of raw materials to China. The diversification of fossil fuel sources by the People's Republic of China may deprive Russia of its most important asset. This is indirectly linked to Russia's loss of its dominant influence in the Central Asian region, because at present the country does not have the investment capital that is being sought by members of the Commonwealth of Independent States. Chinese oil corporations have already begun 
exploiting resource deposits in the region, and with the weakening political and economic influence, Russia will probably be forced accept the Chinese economic and political supremacy in the region. Also, changing the nature of the Shanghai Cooperation Organization's operation towards creating an economic union may lead Russia to even greater economic problems not only in the context of trade with China, but also with other countries in the region.

Diplomatic discrepancies may also have a potential impact on long-term cooperation. China in its own interest has given up its strong reaction to the conflict in Ukraine and Russian involvement in Syria, but it is against China's principle of respecting territorial integrity and non-interference in the internal policies of third countries (Baggiani). Similar friction may be caused by an increase in the volume of Russian arms sales to the countries of Southeast Asia (in particular Vietnam, the Philippines and Malaysia) in the context of supporting different actors of the conflict in the South China Sea. Rise of the tensions can be also caused by lack of agreement on the development of international organizations' forums, including previously mentioned Shanghai Cooperation Organization or the lack of consensus on the establishment of a free trade zone in the Eurasian Economic Union relations with China. Another threat in Sino-Russian relations may also be the growing interest of China in the development of political, military and economic relations with the countries of $16+1$ format as well as with Belarus and Ukraine, which a few decades ago was the exclusive sphere of influence of the USSR.

The problems in the Sino-Russian relations may also be caused by the further military cooperation of the Russian and Belarusian armies, giving the example of Zapad 2017 military drill project in September 2017, openly called the largest military exercises since the Cold War era (Walker). Despite the assurances of Foreign Ministry spokeswoman Maria Zakharova that "Russia does not carry out military exercises or other joint activities that could lead to erosion of bilateral relations with any of the countries," maintaining this format of cooperation may in the long term negatively affect the future of relations between the great powers, namely Russia and China (Marin, 17).

For the arguments mentioned above, there are many limitations of the development of Sino-Russian bilateral relations mainly due to progressive economic asymmetry, which at some point may awaken Russian national pride as a political and military power. China is well aware of the weakening Russia's economic potential, exploiting it in increased exports of fossil fuels as well as technologically and militarily. Reports from August, 2017 suggest that Russia started cooperation with China on space exploration as well as the creation of new satellite system projects (Russia Today). The cooperation contracted for four years, the beginning of which starts in 2018, will probably result in the leaks of Russian technologies and their further independent development in the PRC. 


\section{Works Cited}

Ashraf, J. Impact of Trump Backing out of TPP: An Opportunity for China in the Region. Institute of Strategic Studies (March 2017). Web. 15 Jan. 2018, http:// issi.org.pk/wp-content/uploads/2017/03/Final_IB_Junaid_dated_07-6-2016-1. pdf.

Baggiani, G. China-Ukraine Relations After Crimea. China Brief Volume: 15, The Jamestown Foundation. Web. 16 Jan. 2018, https://jamestown.org/program/ china-ukraine-relations-after-crimea/.

Bartsch, B., Stanzel, A. Sino-US Relations in the Trump Era - A Conflict in the Making? “Trilogue Salzburg” (2017), pp. 116-117. Web. 12 Jan. 2018, https://www. bertelsmann-stiftung.de/fileadmin/files/Faktencheck/Leaders__Dialogues/ Salzburger_Trilog_2017/9_Sino-US_Relations_in_the_Trump_Era.pdf, [accessed: 12.01.2018].

Daly, T. Russia and China are talking about linking currencies to end the US dollar's dominance. Web. 16 Jan. 2018, http://www.businessinsider.com/russiaand-china-discuss-linking-currencies-to-end-the-usd-dominance-2017-11?IR=T.

Financial Express, New Development Bank Approves $\$ 1.4$ bn loan for projects in India, China, Russia. Web. 16 Jan. 2018, http://www.financialexpress.com/economy/ new-development-bank-approves-1-4-bn-loan-for-projects-in-india-chinarussia/833492/.

Higgins, A. China and Russia Hold First Joint Naval Drill in the Baltic Sea. "The New York Times”. Web. 16 Jan. 2018, https://www.nytimes.com/2017/07/25/world/ europe/china-russia-baltic-navy-exercises.html.

ITC Trade Map - International Trade Statistics, https://www.trademap.org/tradestat/ Bilateral_TS.aspx?nvpm=1|156||643||TOTAL|||2| 1|1|1|2|1|1|1|1.

Kowalski, B. Xi Jinping w obronie kapitalizmu. Ośrodek Spraw Azjatyckich Uniwerystetu Łódzkiego (styczeń 2017). Web. 15 Jan. 2018, http://osa.uni.lodz.pl/ xi-jinping-w-obronie-kapitalizmu/.

Manyin, M. Pivot to the Pacific? Obama Administration's "Rebalancing” Toward Asia. Congressional Research Service, CRS Report for Congress (March 2012), p. 2.

Marin, A. Minsk-Beijing: What Kind of Strategic Partnership? Russie.Nei.Visions, no. 102, IFRI (June 2017), pp. 17. Web. 15 Jan. 2018, https://www.ifri.org/sites/ default/files/atoms/files/marin_minsk_beijing_strategic_partnership_2017.pdf.

Menkiszak, M. Russia's Best Enemy. Russian Policy Towards The United States in Putin's Era. "Point of View", no. 62. Ośrodek Studiów Wschodnich, Warszawa, Luty 2017, pp. 33-44.

Ośrodek Spraw Azjatyckich Uniwersytetu Łódzkiego, Raport: Chiny wobec Ukrainy, Białorusi i Rosji - Listopad 2017. Web. 16 Jan. 2018, http://osa.uni.lodz.pl/wpcontent/uploads/2017/12/Chiny_wobec_UBR_listopad_2017.pdf. 
Parker, J.A., Anderson, D.A. The Reality of the So-Called Pivot to Asia. Arthur D. Simons Center for Interagency Cooperation, pp. 11-12. http://thesimonscenter. org/wp-content/uploads/2016/05/IAJ-7-1-Spring2016-5-13.pdf.

Permanent Mission of the People's Republic of China to the UN. Position Paper of the People's Republic of China at the 71st Session of the United Nations General Assembly (08.09.2016). Web. 15 Jan. 2018, http://www.china-un.org/eng/hyyfy/ t1396325.htm.

Polityka Insight, Co przyniesie prezydentura Trumpa? Web. 15 Jan. 2018, http:// zasoby.politykainsight.pl/politykainsight.pl/public/PI-Dossier-Co-przyniesieprezydentura-Trumpa.pdf.

Rampton, R., Zengerle, P. Trump signs Russia sanctions bill, Moscow calls it 'trade war'. Web. 15 Jan. 2018, https://www.reuters.com/article/us-usa-trump-russia/ trump-signs-russia-sanctions-bill-moscow-calls-it-trade-war-idUSKBN1AI1Y4.

Rosneft board approves oil deal with China's CEFC: source. "Reuters". Web. 16 Jan. 2018, https://www.reuters.com/article/us-cefc-rosneft-oil/rosneft-board-approves -oil-deal-with-chinas-cefc-source-idUSKBN1DG1HU.

Rutland, P. Trump, Putin, and the Future of US-Russian Relations, pp. 53. Web. 15 Jan. 2018, https://www.cambridge.org/core/services/aop-cambridge-core/content/vi ew/65BB844AF97639B4BE7671FA8900B53F/S0037677917001577a. pdf/trump_ putin_and_the_future_of_usrussian_relations.pdf.

Walker, S. Vladimir Putin watches display of Russian firepower near EU border. Web. 15 Jan. 2018, https://www.theguardian.com/world/2017/sep/18/ russia-zapad-military-drill-enters-final-phase.

Wright, T. Donald Trump wants America to withdraw from the world. Web. 12 Jan. 2018, https://www.brookings.edu/blog/order-from-chaos/2016/03/24/ donald-trump-wants-america-to-withdraw-from-the-world/.

Przemyslaw Ciborek - PhD candidate at the Department of East Asian Studies, Faculty of International and Political Studies of University of Lodz. He obtained a one-year Chinese language course scholarship at Tianjin University of Science and Technology, China (2015). Former intern of the Embassy of the Republic of Poland in Beijing at the Political, Consular and Agricultural Section (2015). Organizer and coordinator of Summer School Project Understanding Poland, Economy, Society and Science for students from China (2018). Since 2016, he serves as the junior analyst at the Center For Asian Affairs of University of Lodz. His scientific research mainly focuses on Chinese foreign policy towards Central and Eastern Europe with a special regard to Chinese investment policy towards Balkan Peninsula countries. 